\title{
PENGARUH STRATEGI PEMBELAJARAN BERBASIS SELF REGULATED LEARNING DAN PENGETAHUAN AWAL TERHADAP HASIL BELAJAR
}

\author{
Yowelna Tarumasely \\ Dosen IAKN Ambon \\ yowelnatarumasely@gmail.com
}

\begin{abstract}
Abstrack: This study aims to analyze the effect of self-regulated learning-based learning and initial knowledge on learning outcomes for the second semester of Christian Religious Education students. The research subjects were 96 people who were divided into two groups, namely the experimental and control groups. Data obtained by using tests to measure learning outcomes. Data analysis used two-way ANOVA. The results show that there are differences in learning outcomes between self-regulated learning and teacherregulated learning-based learning strategies with high and low initial knowledge levels, and there is an interaction between learning strategies and initial knowledge on learning outcomes. This means that selfregulated learning-based learning and prior knowledge have a better effect on the results of the Learning Theory
\end{abstract}

Key Words: Self Regulated Learning Strategy, Initial Knowledge, Learning Outcomes

\section{Pengantar}

Kemampuan yang dimiliki oleh seseorang setelah mengikuti proses pembelajaran seringkali disebut sebagai hasil belajar, (Kenedy, Hyland, \& Ryan, (2009). Hasil belajar menurut Bloom (dalam Anderson \& Kratwohl, 2010) diklasifikasikan menjadi tiga domain yakni: kognitif, Afektif, dan psiko-motor. Dalam penerapan ketiga ranah terse-but seseorang harus melaluinya secara bertahap, mulai dari tingkat yang paling sederhana sampai ke tingkat yang paling kompleks. Salah satu bentuk pencapaian atau hasil belajar ranah kognitif adalah pemahaman konsep. Pemahaman konsep merupakan dasar pijak bagi sesorang untuk membangun pengetahuan selanjutnya. Dengan pemahaman konsep yang baik akan memudahkan peserta didik untuk mengembangkan kemampuannya. Hal yang sama juga dikemukan oleh Mills,(2016), bahwa pemahaman konsep merupakan suatu dasar untuk mengkonstruk pengetahuan berikutnya.
Penelitian dalam dunia pendidikan yang membahas tentang hasil belajar bagi peserta didik telah banyak dilakukan baik itu yang terkait dengan usia, tingkat pendidikan juga yang terkait dengan bidang lain. Hasil yang ditemukan menunjukan bahwa hasil belajar yang dimiliki oleh peserta didik tidak lengkap atau tidak akurat dalam bidangnya masing-masing. Smith - Ragan mengemukakan bahwa pemahaman konsep bukan sekedar kemampuan untuk menghafal berbagai informasi, tetapi lebih dari itu dibutuhkan suatu kemampuan agar informasi yang telah diperoleh dapat diaplikasi pada pengalaman atau situasi yang tak terduga lainnya (Saricayir et. Al. 2016).

Pentingnya hasil belajar sebagai bentuk penguasaan peserta didik terhadap pelajaran yang telah disampaikan oleh pendidik, dirasakan perlu juga bagi mahasiswa khususnya semester kedua. Mengingat bahwa mahasiswa semester kedua dikategorikan sebagai mahasiswa yang masih baru pada dunia perguruan tinggi, dengan demikian membutuhkan 
proses penyesuaian dengan iklim akademis di perguruan tinggi, salah satu di antaranya adalah strategi pembelajaran. Strategi pembelajaran di perguruan tinggi berbeda dengan strategi pembelajaran yang diperoleh di sekolah menengah, yang mana guru lebih dominan daripada siswa, siswa hanya sebagai pendengar, bahwa guru yang lebih berperan dalam mengatur pembelajaran siswa, tentang kapan, di mana, sumber apa yang akan dipakai sampai bagaimana cara siswa itu belajar atau pembelajaran berpusat kepada guru ( teacher centered learning).

Menurut Vishnumolakala,et.al, (2017) pada Teacher Centered Learning dinamika pembelajaran yang terjadi cenderung menjadikan siswa sebagai penerima informasi ( resptoar pasif ) tanpa mempertimbangkan mereka untuk berpartisipasi secara aktif, sehingga membuat mahasiswa kurang memiliki kemandirian dalam belajar, kurangnya motivasi untuk berusaha, kurangnya kemampuan untuk mentransfer pengetahuan yang dimiliki, kurangnya keyakinan diri terhadap kemampuanya sendiri, kurangnya kemampuan untuk meregulasi diri dalam belajar, dan juga menjadikan mereka tidak ideal dalam mengembangkan ketrampilan berpikir. Sementara Strategi pembelajaran pada perguruan tinggi mahasiswa dituntut untuk lebih aktif, mahasiswa harus diberikan kesempatan untuk mengatur pembelajaran mereka sendiri tentang kapan, di mana, sumber apa yang akan dipakai sampai bagaimana cara belajar.

Strategi pembelajaran yang sesuai dengan hakekat belajar di perguruan tinggi adalah strategi pembelajaran yang memberikan kesempatan kepada mahasiswa mengatur dirinya sendiri untuk belajar atau self regulated learning. Selfregulated learning merupakan kegiatan di mana individu yang belajar secara aktif, menyusun, menentukan tujuan belajar, merencanakan dan memonitor, mengatur dan mengontrol kognisi, motivasi perilaku serta lingkungannya untuk mencapai tujuan yang telah ditetapkan (Pintrich, 2004; Wolters, et. al, 2003). Beberapa hasil penelitian menunjukan bahwa strategi pembelajaran self regulated sangat efektif digunakan sebagai strategi pembelajaran untuk meningkatkan hasil belajar dalam memahami fakta, konsep, prinsip dan prosedur.

Strategi self regulated learning membantu mahasiswa dalam menentukan langkah pertama untuk belajar, menentukan kebutuhan mereka, menetapkan tujuan belajar mereka, mengeksplorasi sumber belajar, mengatur waktu dan lingkungan, dan menerapkannya secara efektif untuk mencapai hasil belajar yang memuaskan (Zhu, Au \& Yates, 2016). Veeanam (1999) mengemukan bahwa strategi Self Regulated Learning berpengaruh terhadap penerapan teori pada praktik pengobatan di dalam kelas. Hal senada juga dikemu-kakan oleh, Oslem Sadi, Miray Uyar (2013) bahwa strategi pembelajaran self regulated learning dapat meningkatkan prestasi akademik.

Selain strategi pembelajaran, salah satu syarat keberhasilan pembelajaran ditentukan oleh karakteristik mahasiswa. Menurut Carey \& carey ( 2001) menyatakan bahwa ;information abaut the group's general characteristic can be very helpuil in planning instruction tailored to group need". Karaktersitik mahasiswa adalah se-luruh latar belakang yang dibawa ketika hadir di kelas sebelum pembelajaran dimulai. Reigeluth (2009) menjelaskan bahwa hasil belajar yang optimal sangat dipengaruhi oleh penerapaan prosedur pembelajaran yang mempertimbangkan system nilai, metode, kondisi (karakteristik) mahasiswa, materi dan tujuan pembelajaran. Oleh Karena itu, do- 
sen dalam melaksanakan pembelajaran di kelas, perlu memperhatikan metode karakteristik mata pelajaran dan tujuan pembelajaran, serta kondisi mahasiswa. Pengetahuan awal (prior knowledge) sebagai karakteristik mahasiswa yang menjadi salah satu unsur penting yang harus diperhatikaan pembelajar dalam merencanakan pembelajaran.

Berkaitan dengan pengetahuan awal penelitian dari Kandeou dan Van Den Broek (2007) menyimpulkan bahwa (1) pembelajar yang memiliki sedikit miskonsepsi lebih suka menggambarkan inferensi yang benar, sebagaimana yang dibaca, (2) pebelajar yang memiliki sedikit miskonsepsi memanggil kembali beberapa idea dari bagian yang dibaca, (3) pembelajar dengan banyak miskonsepsi lebih suka mendeteksi dan membenarkan ide salahnya jika teks secara jelas membantah idenya.

\section{Tinjauan Literatur Hasil Belajar}

Pemahaman konsep merupakan aspek penting yang perlu diperhatikan oleh seorang pembelajar. Pemahaman konsep menurut Bloom dimasukan pada domain kognitif. Sagala (2011) mengemukakan bahwa pemahaman adalah kemampuan intelektual untuk menangkap makna atau arti sesuatu hal. Bloom menjelaskan pengertian pemahman konsep, yang mengandung indicator di dalamnya yaitu kemampuan menangkap pengertian, penterjemahkan, dan menafsirkan (regeilutuh dan Moore,1999) sedangkan reigeluth Chelimen (2009) mengatakan bahwa Comprehension is higher-level learning outcome asking for students to graps meanings such as distinguish, predict, and so forth.

\begin{abstract}
Pemahaman seseorang juga dicirikan oleh kemampuan dalam mengartikulasi-kan sesuatu melalui caracara mengemu-kakan gagasan, perspektif, solusi dan produk mereka yang siap direnungkan, dikritik, dan digunakan oleh orang lain (Dunlap dan Grrabinger, 1996). Willis (2000) mengemukakan Seorang dikatakan memahami apabila ia dapat menunjukan unjuk kerja pemahaman konsep tersebut pada level kemampuan yang lebih tinggi baik pada konteks yang sama maupu pada konteks yang berbeda.
\end{abstract}

\section{Strategi Self Regulated Learning}

Zimmerman adalah orang pertama yang menulis tentang self regulated learning (Ernesto Panadero,2015). Ada beberapa penjelasan teoritis dan perspketif tentang self regulated learning seperti teori kognitif social, teori kehendak dan fenemologi (Zimmerman, 2001). Self regulated learning menunjukan kemampuan mahasiswa untuk secara aktif dan sengaja menetapkan tujuan untuk pembelajaran mereka dan untuk memantau, mengatur, mengendalikan dan mengevaluasi kognisi, perilaku, motivasi dan lingkungan mereka untuk mencapai tujuan belajar mereka (Pintrich, 2004; Zimmerman, 2001). Pintrich (2000) menggambarkan self regulated learning sebagai: "proses aktif dan konstruktif di mana mahasiswa menetapkan tujuan untuk pembelajaran mereka dan kemudian mencoba memantau, mengatur, dan mengendalikan kognisi mereka, motivasi dan perilaku, serta dibimbing dan dibatasi oleh tujuan dan fitur kontekstual yang sesuai lingkungannya.

Dalam proses aktivasi belajar penerapan strategi self regulated learning, 
untuk memandu mahasiswa proaktif belajar menggunakan model Pintrich 2004, yakni: 1) forethought, planning, and activation, 2) Monitoring, 3) controlling, dan 4) reaction and reflection. Berdasarkan langkah- langkah SRL yang dikemukakan oleh Pintrich tersebut maka dibuatlah langkah- langkah strategi pembelajaran berbasis self regulated learning, seperti pada table di bawah ini:

Table 1. Langkah - langkah Strategi pembelajaran berbasis Self Regulated Learning Pada Mata Kuliah Teori Belajar.

\begin{tabular}{|c|c|c|c|}
\hline \multicolumn{2}{|c|}{ Prosedur } & \multicolumn{2}{|c|}{ Aktivitas } \\
\hline $\begin{array}{l}\text { Kegiatan } \\
\text { pembelajaran }\end{array}$ & $\begin{array}{ll}\text { Strategi } & \text { Self } \\
\text { Regulated } & \\
\text { Learning } & \\
\end{array}$ & Dosen & Mahasiswa \\
\hline $\begin{array}{l}\text { Kegiatan } \\
\text { pendahuluan }\end{array}$ & $\begin{array}{l}\text { Forethought, } \\
\text { planning and } \\
\text { activation }\end{array}$ & $\begin{array}{l}\text { Menyampaikan } \\
\text { tujuan } \\
\text { pembelajaran }\end{array}$ & $\begin{array}{l}\text { 1. Mahasiswa } \\
\text { mendengar, } \\
\text { mencatat. } \\
\text { 2. Mahasiswa } \\
\text { menganalisis } \\
\text { tugas belajarnya } \\
\text { berdasarkan } \\
\text { tujuan } \\
\text { pembelajaran } \\
\text { yang } \\
\text { disampaikan } \\
\text { 3. Mahasiswa } \\
\text { menentukan } \\
\text { tujuan belajarnya } \\
\text { 4. Mahasiswa } \\
\text { menentukan cara } \\
\text { strategi } \\
\text { belajarnya. } \\
\text { 5. Mahasiswa aktif } \\
\text { mencari } \\
\text { informasi dengan } \\
\text { beberapa sumber, } \\
\text { modul, internet, } \\
\text { perpustakaan, dll }\end{array}$ \\
\hline Kegiatan inti & $\begin{array}{l}\text { Monitoring } \\
\text { Controlling }\end{array}$ & $\begin{array}{l}\text { 1.Memonitoring } \\
\text { aktivitas } \\
\text { mahasiswa. } \\
\text { 2. Mengonrol } \\
\text { aktivitas } \\
\text { mahasiswa } \\
\text { ( Untuk fase ini } \\
\text { dosen dapat } \\
\text { membantu } \\
\text { mahasiswa } \\
\text { apabila } \\
\text { menemui } \\
\text { kendala ) }\end{array}$ & $\begin{array}{l}\text { 1. Memonitoring } \\
\text { kemajuan dalam } \\
\text { menyelesaikan } \\
\text { tugas, dan } \\
\text { memantau } \\
\text { keefektifan } \\
\text { strategi yang } \\
\text { dipilih } \\
\text { 2. memantau } \\
\text { motivasi } \\
\text { menyelesaikan } \\
\text { tugas. } \\
\text { ( mahasiswa dapat } \\
\text { bertanya kepada } \\
\text { dosen atau } \\
\text { teman) }\end{array}$ \\
\hline $\begin{array}{l}\text { Kegiatan } \\
\text { penutup }\end{array}$ & $\begin{array}{l}\text { Reaction } \\
\text { reflection }\end{array}$ & \begin{tabular}{|l} 
Mengevaluasi \\
kinerja sesuai \\
sesuai dengan \\
standar
\end{tabular} & \begin{tabular}{|l|} 
Mengevaluasi \\
kinerja pada \\
tugas belajar \\
- Mengelola \\
respons emosional \\
terkait dengan hasil
\end{tabular} \\
\hline
\end{tabular}

\section{Pengetahuan Awal}

Pengetahuan awal yang dimiliki pebelajar sangat berpengaruh terhadap kemampuannya mempelajari sesuatu hal yang baru. Pengetahuan awal yang diperoleh melalui pembelajara sebelumnya sangat berpengaruh terhadap prestasi mahasiswa. Santrock (2008;311) mengatakan bahwa pebelajar menggunakan pengetahuan awal dan strategi yang telah mereka pelajarai untuk menyesuaikan respons pada pembelajaran yang baru, dengan menggunakan pengetahuan awal dan strategi sebelumnya pebelajar akan membangun respons baru dan lebih baik.

Stangmen \& Hall,2012: latar belakang pengetahuan atau Background knowledge terkait dengan pengetahuan yang spesifik seprti pengetahuan konseptual dan pengetahuan metakognitif. Hailikari, dkk (2008) pengetahuan awal adalah sesutau yang multidemisi dan bertingkat yang dinamis, bersifat alami dan konsisten atas tipe pengetahuan berdasarkan latar belakang yang dimiliknya. Chaera (2010) keseluruhan pengetahuan actual yang dimiliki seseorang sebelum belajar, terstruktur dalam sebuah skemma, bisa deklaratif dan prosedural, sebagian ekspelisit dan sebagain tidak, secara dinamis dan tersimpan dalam basis pengetahuan.

\section{Metode}

Penelitian ini menggunakan penelitian kuasi ekperimen untuk menguji hipotesis mengenai hubungan sebab akibat antar variable (Degeng, 2000:13). Desain penelitian yang digunakan adalah desain factorial 2 x 2 (Degeng, 2000:15, Setyosari, 2012:180). Desain penelitian tersebut dapat dilihat pada table 1 .

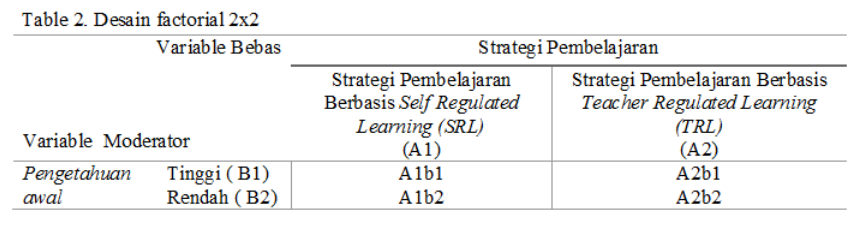


1. Kelompok A1B1 : Hasil belajar dengan strategi pembelajaran berbasis Self Regulated Learning dan pengetahuan awal tinggi

2. Kelompok A1B2 : Hasil belajar dengan strategi pembelajaran berbasis Self Regulated Learning dan pengetahuan awal rendah

3. Kelompok A2B1 : Hasil belajar dengan strategi pembelajaran berbasis teacher Regulated Learning dan pengetahuan awal tinggi

4. Kelompok A2B2 : Hasil belajar dengan strategi pembelajaran berbasis teacher Regulated Learning dan pengetahuan awal tinggi

Subjek penelitian adalah mahasiswa semester dua program studi Pendidikan Agama Kristen pada Institut Agama Kristen Negeri Ambon tahun akademik 2017/2018, yang terdiri 4 kelas paralel (kelas A,B,C, dan D). Masing-masing kelas berjumlah 23 orang sehingga jumlah keseluruhan berjumlah 96 orang, selanjutnya dibagi menjadi dua kelompok yakni kelompok eksperimen dan kelompok control. Kelas eksperimen adalah kelas A dan kelas B, sedangkan kelas C dan kelas D adalah kelompok control. Selama proses pembelajaran berlangsung, semua mahasiswa mengikuti dari awal kegiatan pembelajaran sampai akhir, baik untuk kelas eksperimen maupun kelas control, dengan demikian subjek penelitiannya berjumlah 96 orang. Untuk lebih jelasnya tentang subyek penelitian dapat dilihat pada table berikut ini:
Table 3. Subyek Penelitian Berdasarkan Kelompok Eksperimen dan Kelompok Kontrol

\begin{tabular}{|l|c|c|c|c|c|}
\hline \multirow{2}{*}{ No } & \multicolumn{2}{|c|}{ Kelompok Eksperimen } & \multicolumn{2}{c|}{ Kelompok Kontrol } & \multirow{2}{*}{ Jumlah Mahasiswa } \\
\cline { 2 - 5 } & Kelas & Jumlah Mahasiswa & Kelas & Jumlah Mahasiswa & \\
\hline 1 & $\mathrm{~A}$ & 23 & $\mathrm{C}$ & 23 & 46 \\
2 & $\mathrm{~B}$ & 23 & $\mathrm{D}$ & 23 & 46 \\
\hline Total & 2 & 46 & 2 & 46 & 96 \\
\hline
\end{tabular}

Instrumen yang digunakan dalam penelitian ini tediri dari tes. Bentuk Tes adalah pilihan ganda, untuk mengukur pemahaman konsep. Jumlah soal yang dipakai sebanyak 25 butir soal dengan skor nilai untuk jawaban benar 1 dan skor nilai 0 untuk jawaban yang salah. Sedangkan pengetahuan awal, data diperoleh dari Nilai IPK mahasiswa. Untuk mengelompokan subyek penelitian berdasarkan pengetahuan awal tinggi atau rendah, dilakukan dengan mengelompokan mahasiswa dengan nilai IPK $\geq 3,00$ dikelompokan dalam subjek penelitian dengan pengetahuan awal tinggi dan subyek penelitian yang memperoleh nilai IPK $\leq$ 2,99 dikelompokkan dalam subyek penelitian dengan pengetahuan awal rendah..

Data yang dianalisis terbagi dua, yang pertama sebagai persyaratan untuk melakukan analisis ANOVA dan yang kedua untuk menguji hipotesis penelitian. Untuk persyaratan analisisnya berupa uji normalitas data dan uji homogenitas. Uji normalitas data menggunakan Kolmogorov-Smirnov dan uji homogenitas varians menggunakan Levene's test. Uji normalitas data dan homogenitas untuk memenuhi asumsi parametric sebagai persyaratan uji ANOVA. Analisis data untuk menguji hipotesis penelitian menggunakan teknik statistic ANOVA dua jalur dengan program SPSS for Windows. 
Dan semua uji asumsi parame-tric dilakukan pada nilai signifikansi $5 \%$.

\section{HASIL}

\section{Deskripsi Hasil Pretest Hasil Belajar}

Sebelum dilakukan penelitian dan pemberian treatment, terlebih dahulu dilakukan pretest kepada mahasiswa yang akan terlibat dalam penelitian untuk mengetahui kemampuan awal yang dimiliki oleh mereka terkait dengan Mata Kuliah Teori Belajar. Hasil pretest seperti pada table di bawah ini:

Tabel 2. Hasil Pretest Hasil Belajar.

\begin{tabular}{lccccc}
\hline & N & Min & Max & Mean & Std.D \\
\hline Pretest (Kelas Eksperimen ) & 46 & 60 & 72 & 66,17 & 4,276 \\
\hline Pretest (Kelas Kontrol) & 46 & 60 & 72 & 65,48 & 4,247 \\
\hline Valid N (Listwise) & 60 & & & & \\
\hline
\end{tabular}

Tabel 2 menunjukan bahwa nilai rata- rata hasil pretest hasil belajar untuk kelas eksperimen sebesar 66,17, dengan standar deviasi sebesar 4,276, sementara itu nilai rata rata yang diperoleh kelas kontrol sebesar 65,48, dengan standar deviasi sebesar 4,247. Nilai rata-rata pretest kelas eksperimen lebih tinggi dari kelas control.

\section{Deskripsi Pengetahuan Awal.}

Pengetahuan awal sebagai variabel moderator terbagi atas dua yakni pengetahuan awal tinggi dan pengetahuan awal rendah. Tabel berikut menyajikan hasil pengukuran kelompok subjek penelitian berdasarkan strategi pembelajaran dan pengetahuan awal
Table 3. Deskripsi Subyek Penelitian Berdasarkan Strategi Pembelajaran dan pengetahuan awal

\begin{tabular}{|l|c|c|c|}
\hline \multirow{2}{*}{ Kelas } & \multicolumn{2}{|c|}{ Pengetahuan Awal } & \multirow{2}{*}{ Total } \\
\cline { 2 - 3 } & Tinggi & Rendah & \\
\hline Self Regulated Learning & 23 & 23 & 46 \\
\hline Teacher Regulated Learning & 23 & 23 & 46 \\
\hline Total & 46 & 46 & 92 \\
\hline
\end{tabular}

Table 3 menunjukan bahwa pengetahuan awal untuk kelas eksperimen (strategi pembelajaran berbasis self regulated learning) kelompok subjek yang memiliki pengetahuan awal tinggi sebesar 23 orang, dan yang memiliki pengetahuan awal rendah sebanyak 23 orang, demikian juga untuk kelas control (strategi pembelajaran berbasis teacher regulated learning) kelompok subjek yang memiliki self efficaci tinggi sebesar 23 orang, dan yang memiliki pengetahuan awal rendah sebanyak 23 orang.

\section{Deskripsi Hasil Posttest Hasil Belajar}

Hasil post test pemahaman konsep dalam penelitian ini diperoleh setelah kelompok subyek penelitian mendapat perlakuan dengan strategi pembelajaran berbasis self regulated learning dan strategi pembelajaran berbasis teacher regulated learning. Hasil posttest pemahaman konsep ditunjukan pada table 4 dibawah ini.

Table 4 Data Posttest Hasil Belajar Pemahaman Konsep

\begin{tabular}{|l|l|c|c|c|}
\hline \multicolumn{1}{|c|}{$\begin{array}{c}\text { Strategi } \\
\text { Pembelajaran }\end{array}$} & $\begin{array}{c}\text { Pengetahuan } \\
\text { awal }\end{array}$ & Mean & Std. Deviation & $\mathrm{N}$ \\
\hline \multirow{2}{*}{$\begin{array}{l}\text { Self Regulated } \\
\text { Learning }\end{array}$} & Tinggi & 79.48 & 5.160 & 23 \\
\cline { 2 - 5 } & Rendah & 69.04 & 5.423 & 23 \\
\cline { 2 - 5 } & Total & 74.26 & 7.431 & 46 \\
\hline \multirow{2}{*}{$\begin{array}{l}\text { Teacher Regulated } \\
\text { Learning }\end{array}$} & Tinggi & 74.96 & 5.148 & 23 \\
\cline { 2 - 5 } & Rendah & 66.43 & 4.305 & 23 \\
\cline { 2 - 5 } & Total & 70.70 & 6.370 & 46 \\
\hline \multirow{3}{*}{ Total } & Tinggi & 77.22 & 5.585 & 46 \\
\cline { 2 - 5 } & Rendah & 67.74 & 5.017 & 46 \\
\cline { 2 - 5 } & Total & 72.48 & 7.112 & 92 \\
\hline
\end{tabular}


Table 4 di atas menunjukan hasil belajar kelompok eksperimen yakni strategi pembelajaran berbasis self regulated learning dengan kelompok mahasiswa yang memiliki pengetahuan awal tinggi berjumlah 23 orang memperoleh nilai rata-rata sebesar 79.48, dengan standar deviasi sebesar 5.160, mahasiswa yang memiliki pengetahuan awal rendah sejumlah 23 orang memperoleh nilai ratarata sebesar 69,04, dengan standar deviasi sebesar 5,423. Selanjutnya hasil belajar yang diperoleh oleh kelas control, kelas yang diajarkan dengan menggunakan strategi pembelajaran berbasis teacher regulated learning dengan pengetahuan awal tinggi memperoleh nilai rata-rata sebesar 74,96, dengan standar deviasi sebesar 5,148. Sementara kelompok mahasiswa yang memiliki pengetahuan awal yang rendah memperoleh nilai rata-rata sebesar 66,43, dengan standar deviasi sebesar 4,305

Hasil posttes menunjukan, ada perbedaan yang signifikan hasil belajar kelompok eksperimen dengan kelompok kontrol. Berdasrkan hasil postetst nilai rata - rata dari hasil belajar untuk kelas eksperimen adalah sebesar 74,26 dengan standar deviasi sebesar 7,431 dan kelas control sebesar 70,70 dengan standar deviasi sebesar 6,370. Hal ini menunjukan bahwa nilai rata - rata kelas eksperimen lebih tinggi dari nilai rata-rata kelas control.

Dari hasil postest score hasil belajar untuk kelompok mahasiswa yang memiliki pengetahuan awal tinggi memperoleh nilai rata- rata sebesar 77,22 dengan standar deviasi sebesar 5,585, sementara score hasil belajar untuk kelompok mahasiswa yang memiliki pengetahuan awal rendah memperoleh nilai rata-rata sebesar 67,74 dengan standar deviasi sebesar 5,017. Hal ini menunjukan bahwa kelompok mahasiswa yang memiliki pengetahuan awal tinggi, hasil belajar lebih baik daripada kelompok mahasiswa yang memiliki pengetahuan awal rendah.

\section{Uji Persyaratan Analisis}

Untuk melakukan pengujian terhadap hipotesis yang diajukan dalam penelitian ini, maka variabel - variabel yang diteliti baik itu variabel bebas yakni strategi pembelajaran berbasis self regulated learning dan strategi pembelajaran berbasis teacher regulated learning, variabel moderator yaitu pengetahuan awal dan variabel terikat yakni hasil belajar, diuji dengan menggunakan analisis ANOVA (Analysis of Variance), sebelum melakukan analisis terlebih dahulu dilakukan pemeriksaan data hasil penelitian dengan uji persyaratan analisis ANOVA, yang meliputi uji normalitas dan homogenitas varians.

\section{Uji Normalitas}

Uji normalitas digunakan untuk mengetahui data berdistribusi normal ataukah tidak sebagai salah satu uji prasyarat untuk melakukan uji analisis ANOVA dua jalur. Berikut hasil uji normalitas data posttest hasil belajar:

Tabel 5. Hasil Uji Normalitas Data Posttest Hasil Belajar Pemahaman Konsep

\begin{tabular}{l|l|r|r|r|r|r|r|}
\hline \multirow{2}{*}{} & \multirow{2}{*}{$\begin{array}{l}\text { Strategi } \\
\text { Pembelajaran }\end{array}$} & \multicolumn{4}{|c|}{ Kolmogorov-Smirnov $^{2}$} & \multicolumn{3}{|c|}{ Shapiro-Wilk } \\
\cline { 3 - 8 } & Statistic & Df & Sig. & Statistic & Df & Sig. \\
\hline HASIL & SRL & .120 & 46 & .097 & .962 & 46 & .131 \\
\cline { 2 - 9 } BELAJAR & TRL & .151 & 46 & .011 & .958 & 46 & .099 \\
\hline
\end{tabular}

Berdasarkan table di atas hasil uji normalitas menggunakan KolmogorovSmirnov menunjukan bahwa nilai signify- 
kansi hasil belajar untuk strategi pembelajaran berbasis self regulated learning dan teacher regulated learning lebih besar dari 0,05 ( 0,97>0,05, 0,11>0,05 ). Hal ini berarti data hasil belajar pemahaman konsep berdistribusi normal.

\section{Uji Homogenitas}

Uji homogenitas untuk menentukan homogenitas varians data skor hasil belajar menggunakan Levene's test, berikut disajikan hasil uji homogenitas pada tabel di bawah ini:

Table 6. Hasil Uji Homogenitas Data Posttest Hasil Belajar

\begin{tabular}{|c|c|c|c|}
\hline $\mathrm{F}$ & $\mathrm{df1}$ & $\mathrm{df} 2$ & Sig. \\
\hline .213 & 3 & 88 & .887 \\
\hline
\end{tabular}

Berdasarkan table di atas hasil uji homogenitas menunjukan bahwa nilai signifikansi untuk hasil belajar untuk strategi pembelajaran berbasis self regulated learning dan teacher regulated learning lebih besar dari 0,05 ( 0,887 >0,05). Hal ini berarti data mempunyai matriks varians homogen.

\section{Pengujian Hipotesis Penelitian}

Hipotesis penelitian ini terdiri atas tiga:

1) Ho-1: tidak ada perbedaan hasil belajar teori belajar antara mahasiswa yang diajarkan dengan strategi pembelajaran berbasis self regulated learning dengan mahasiswa yang diajarkan dengan strategi pembelajaran berbasis teacher regulated learning.

Ha-1: ada perbedaan hasil belajar teori belajar antara mahasiswa yang diajarkan dengan strategi pembelajaran berbasis self regulated learning dengan mahasiswa yang diajarkan dengan strategi pembelajaran berbasis teacher regulated learning.

2) Ho-3: tidak ada interaksi antara strategi pembelajaran dengan pengetahuan awal terhadap hasil belajar teori belajar

Ha-3: tidak ada interaksi antara strategi pembelajaran dengan pengetahuan awal terhadap hasil belajar teori belajar.

Untuk menguji hipotesis di atas berikut dipaparkan hasil analisis ANOVA berupa uji efek antar subjek ( Test of Between- subject Effects) pada table di bawah ini:

Table 7. Hasil Analisis ANOVA Dua Jalur Test of Between-Subject Effects

\begin{tabular}{|l|r|r|r|r|r|}
\hline Source & $\begin{array}{c}\text { Type III Sum } \\
\text { of Squares }\end{array}$ & \multicolumn{1}{c|}{ df } & Mean Square & \multicolumn{1}{c|}{ F } & \multicolumn{1}{c|}{ Sig. } \\
\hline Corrected Model & $2379.652^{2}$ & 3 & 793.217 & 31.396 & .000 \\
\hline Intercept & 483285.043 & 1 & 483285.043 & 19128.773 & .000 \\
\hline STRATEGI & 292.348 & 1 & 292.348 & 11.571 & .001 \\
\hline $\begin{array}{l}\text { PENGETAHUAN } \\
\text { AWAL }\end{array}$ & 2066.261 & 1 & 2066.261 & 81.784 & .000 \\
\hline $\begin{array}{l}\text { STRATEGI * } \\
\text { PENGET AHUAN } \\
\text { AWAL }\end{array}$ & 301.043 & 1 & 301.043 & 13.833 & .003 \\
\hline Error & 2223.304 & 88 & 25.265 & & \\
\hline Total & 487888.000 & 92 & & & \\
\hline Corrected Total & 4602.957 & 91 & & & \\
\hline
\end{tabular}

Hasil uji hipotesis pertama bedasarkan uji Anova 2 jalur pada table 7 diatas menunjukan bahwa untuk strategi pembelajaran nilai $\mathrm{F}$ hitung sebesar 11,571 dan nilai signifikansi sebesar 0,01. Nilai signifikansi lebih kecil dari $0,05(0,01$ $<0,05)$. Dengan demikian hipotesis nol ditolak, hal ini berarti ada perbedaan yang signifikan hasil belajar antara kelompok yang diajarkan dengan strategi pembelajaran berbasis self regulated learning dengan kelompok yang diajarkan dengan startegi bpembelajaran berbasis teacher regulated learning.

Hasil uji hipotesis kedua bedasarkan uji Anova 2 jalur pada table 7 diatas menunjukan bahwa nilai $\mathrm{F}$ hitung 
sebesar 81,784 dan nilai signifikansi sebesar 0,00. Nilai signifikansi lebih kecil dari $0,05 \quad(0,00<0,05)$. Dengan demikian hipotesis nol ditolak, hal ini berarti ada perbedaan yang signifikan hasil belajar pemahaman konsep antara kelompok yang memiliki pengetahuan awal tinggi dengan kelompok yang memiliki pengetahuan awal rendah. Hal ini menunjukan bahwa mahasiswa yang memiliki pengetahuan awal tinggi memiliki hasil belajar pemahaman konsep lebih baik dibandingkan kelompok mahasiswa yang memiliki self efficaci rendah.

Hipotesis ketiga adalah ada interaksi antara strategi pembelajaran dan pengetahuan awal terhadap hasil belajar. Hasil uji Anova 2 jalur pada table 7 diatas menunjukan bahwa nilai $\mathrm{F}$ hitung sebesar 13,833 dan nilai signifikansi sebesar 0,03. Nilai signifikansi lebih kecil dari 0,05 $(0,03<0,05)$. Dengan demikian hipotesis nol ditolak, hal ini berarti ada interaksi antara strategi pembelajaran dan pengetahuan awal terhadap hasil belajar Teori Belajar.

\section{Pembahasan}

Berdasarkan hasil uji hipotesis, maka hipotesis pertama dalam penelitian ini yaitu: ada perbedaan hasil belajar antara mahasiswa yang menggunakan strategi pembelajaran berbasis self regulated learning dengan kelompok mahasiswa yang menggunakan pembelajaran berbasis teacher regulated learning diterima. Hal ini berarti bahwa kelompok mahasiswa yang menggunakan strategi pembelajaran berbasis self regulated learning memperoleh hasil belajar lebih tinggi dibandingkan dengan kelompok mahasiswa yang menggunakan strategi pembe- lajaran berbasis teacher regulated learning.

Hasil penelitian ini mendukung hasil penelitian Najva Najabati (2015) strategi self regulated learning mempengaruhi pemahaman membaca, sebagaimana yang diungkapkan oleh Zhu,Au \& Yates (2016), membantu mahasiswa menentukan langkah-langkah untuk belajar dan dapat meningkatkan hasil belajar apabila langkah-langkah tersebut diterapkan secara efektif.

Hal ini juga didukung oleh penelitian Siti Fatimah, (2013) bahwa strategi self regulated learning meningkatkan prestasi belajar. Penelitian ini menemukan bahwa dalam penerapan strategi pembelajaran berbasis self regulated learning, mahasiswa menggunakan kemampuan Metakognisi sehingga dapat membuat tahapan tahapan untuk membantu mereka belajar. Tahapan-tahapan tersebut antara lain; pertama adalah Forethought, planning and activation atau tahap perencanaan, Tahap kedua monitoring (controlling) monitoring atau pengawasan, dan tahap ketiga Reaction and reflection atau tahap evaluasi, menurut Pintrich (1999) perilaku tersebut merupakan strategi regulasi yang dapat menolong mahasiswa untuk merencanakan belajarnya dan mengevaluasi sehingga dapat meningkatkan prestasi belajar.

Hasil uji hipotesis kedua menunjukan bahwa terdapat perbedaan hasil belajar yang signifikan antara kelompok dengan pengetahuan awal tinggi dengan pengetahuan awal. Hasil peneitian ini didukung oleh Bandura bahwa mahasiswa dengan pengetahuan awal tinggi akan memperoleh hasil yang baik sebaliknya mahasiswa dengan pengetahuan awal 
yang rendah akan mendapatkan hasil belajar kurang.

Mahasiswa dengan pengetahuan awal tinggi, memiliki tingkat keyakinan diri yang tinggi akan kemampuan yang dimiliki, keyakinan itu mendorong mereka untuk belajar, untuk mencari sumber-sumber informasi untuk menyelesaikan tugas yang diberikan, sementara dengan pengetahuan awal rendah, keyakinan akan kemampuan yang dimiliki relative kecil, mereka tidak yakin bahwa mereka mampu untuk mendapatkan hasil belajar yang lebih baik. Hasil penelitian ini mendukung hasil Floris, et.al, (2012), pengetahuan awal dapat meningkatkan prestasi belajar pengeta-huan awal tinggi memiliki prestasi akademik tinggi sebaliknya mahasiswa dengan pengetahuan awal rendah memiliki kinerja yang rendah. Juga penelitian Wetzels et al (2011) aktivasi pengetahuan awal dapat membuat pebelajar untuk belajar sendiri dan meningkatkan hasil belajar.

Hasil uji hipotesis ketiga menunjukan bahwa ada interaksi antara strategi pembelajaran dan pengetahuan awal. Hasil penelitian ini didukung oleh Nurlaela (2012) self regulated learning melalui pengetahuan awal dapat menghasilkan kinerja dan prestasi akademik yang lebih tinggi. Juga penelitian

\section{Simpulan}

Berdasarkan hasil penelitian dan pembahasan di atas dapat disimpulkan bahwa 1) strategi pembelajaran berbasis self regulated learning memberikan pengaruh positif terhadap hasil belajar mata kuliah Teori belajar. Dengan demikian dapat disimpulkan bahwa ada perbedaan signifikan hasil belajar. Hal ini berarti strategi pembelajaran berbasis self regulated learning perpengaruh positif terhadap hasil belajar Teori Belajar diban- dingkan dengan strategi pembelajaran berbasis teacher regulated learning. 2). pengetahuan awal tinggi memberikan pengaruh positif terhadap hasil belajar Teori Belajar, dan 3) ada interaksi antara strategi pembelajaran dan pengetahuan awal terhadap hasil belajar. Berdasarkan hasil penelitian dan pembahasan di atas juga dapat disimpulkan bahwa strategi self regulated learning dan pengetahuan awal yang tinggi sangat effektif, untuk itu strategi ini sangat tepat untuk diterapkan dalam proses pembelajaran dalam upaya meningkatkan hasil belajar dengan memperhatikan pengetahuan awal mahasiswa.

\section{Saran dan Rekomendasi.}

Berdasarkan kesimpulan hasil penelitian, terbukti bahwa Strategi Self Regulated Learning terbukti efektif utuk meningkatkan hasil belajar mahasiwa pada mata kuliah Teori Belajar, maka diberikan saran sebagai berikut:

1. Kepada dosen pengampuh mata kuliah Teori Belajar agar Strategi pembelajaran berbasis SRL dapat dijadikan acuan bagi pembelajar sebagai salah satu strategi untuk meningkatkan hasil belajar, karena strategi pembelajaran berbasis SRL lebih memberikan kebebasan untuk pebelajar mengatur jalannya proses belajarnya, pembelajar hanya sebagai pendamping dalam proses pembelajaran.

2. Kepada Mahasiswa yang akan mengikuti pembelajaran dengan menggunakan Strategi pembelajaran berbasis SRL, agar memiliki pengetahuan awal yang baik tentang mata kuliah yang akan diajarkan. Hal ini penting karena Strategi pembelajaran berbasis SRL, membutuhkan kemandirian mahasiswa untuk mengatur proses pembelajarannya sendiri. 


\section{Keterbatasan Penelitian}

Penelitian ini hanya terbatas pada mata kuliah Teori belajar, dan subjek penelitian hanya terbatas pada mahasiswa, dan variabel antara adalah pengetahuan awal, sehingga disarankan bagi peneliti lain untuk dapat melakukan penelitian pada mata pelajaran atau mata kuliah yang lain, pada subjek penelitian yang lain dan variabel antara yang lain selain pengetahuan awal.

\section{Ucapan Terima kasih.}

Pelaksanaan penelitian ini tidak terlepas dari dukungan banyak pihak, untuk itu perkenankan penulis untuk mengucapkan terima kasih yang sebesar- besarnya kepada:

1. Rektor Institut Agama Kristen Negeri Ambon

2. Dekan Fakultas Ilmu Pendidikan Kristen IAKN Ambon

3. Kaprodi Pendidikan Agama Kristen

4. Dosen Pengampuh Mata kuliah Teori Belajar

5. Mahasiswa

Atas kesempatan yang diberikan bagi peneliti untuk melakukan penelitin ini.

\section{Pustaka Acuan}

Bandura, A. 1986. Social Foundations of Thought and Action: A Social Cognitive Theory. Englewood Cliffs, NJ: Prentice Hall.

Anderson, L.W., \& Kratwohl, D.R., Airasian, P.W., Cruikshank,KA., Mayer P.E, Pintrich, Raths, J., M Wittrock,M.C., 2010, A Taxonomy for Leaarning Teaching and Assesing: A Revision of Bloom Taxonomy of Educational Objectives, (Eds) Abridges Edition: New York: Longman
Cheng, E.C. (2011). The role of selfregulated learning in enhancing learning performance. The International Journal of Research and Review, 6 (1), 116.

C. Pauli, K. Reusser, and U. Grob, "Teaching for understanding and/or self-regulated learning? A video-based analysis of reformoriented mathematics instruction in Switzerland," International Journal of Educational Research, vol. 46, no. 5, pp. 294-305, 2007.

Degeng, I.N.S. 1989. Ilmu Pengajaran Taksonomi Variabel. Jakarta: Depdikbud, Ditjendikti, P2LPTK.

Dick, W., Carey, L.M., \& Carey, J.O. (2001). The Systematic Design of Instruction: Longman

Dunlap dan Grrabinger,1996. Rich environments for active learning in action: Problem-based learning

Floris, et.al, 2012, Relevant prior knowledge moderates the effect of elaboration during small group discussion on academic achievement

Hailikari, T., Katajavuori, N. \& Ylanne, S.L. 2008. TheRelevance of Prior Knowledge in Learning and In-structional Design. American Journal of Pharmaceutical Education, 72(5):113. (Online), (http://www.ncbi.nlm.nih. gov/pmc/articles/PMC2630138/, diakses 27 Februari 2013).

Ryan, N \& Kennedy, D., Hyland, Á. (2009). Learning Outcomes and Competences, 1(18), 1-18. 
Najva Najabati (2015) Self-Regulated

Learning Strategies improves reading skills

Nurlaela, (2012) Pengaruh Strategi Self Regulated Learning, Motivasi Berprestasi dan Locus Of Control Terhadap Hasil Belajar Maintance Repair Mahasiswa SMK.

Oslem Sadi, Miray Uyar,2013. Relationship Between SelfEfficacy, Self-Regulated Learning Strategies and Achievement: A Path Model

Panadero, E. Jonsoon, A. \& Botella, J. 2017. Effects of Self Assesment on Self Regulated Learning and Self Efficacy: Four Meta Analysis. EducationalResearch Review.1-68.

Pintrich, P.R. 2000. The Role of goal orientation in self-regulated learning. In M. Bokaerts, P. Pintrich, \& M. Zeidner (Eds) Handbook of self-regulation. San Diego, CA: Academic Press, pp. 452-502.

Punaji Setyosari,2013. Metode Penelitian Pendidikan dan Pengembangan, PT Kharisma Putra Utama. Jakarta.

Reigeluth, C.M 2017, Instructional Design Theories and Models: A New Paradigm of Intructional Theory Vol II. New Jersey: Lawrence Erlbaum Associates, Publishers.

Santrock.J.W， (2008) Psikologi Pendidikan, Kencana Prenada Media Group, Jakarta.

Sagala, S. (2010). Konsep dan Makna Pembelajaran. Bandung: Alfabeta.

Zimmerman.BJ. 1998. Self Regulated and Performance: Issues and Educational Application.
Hillsdale, NJ: Lawrence $L$ Erlbaum Association, Inc.

Saricayir et. Al. 2016. Determining Students' Conceptual Understanding Level of Thermodynamics

Setyosari , 2012 Metode penelitian pendidikan dan pengembangan. Kencana, 2012

Siti Suminarti \& Siti Fatimah,2013, SelfRegulated Learning (Srl) Dalam Meningkatkan Prestasi Akademik Pada Mahasiswa, Jurnal Ilmiah Psikologi Terapan ISSN: 2301-8267 Vol. 01, No.01, Januari 2013.

S. Veenman, D. Beems, S. Gerrits, and G. Op de Weegh, "Implementation effects of a training program for self-regulated learning," Journal of Research \& Development in Education, vol. 32, no. 3, pp. 148-159, 1999. View at Google Scholar

Tzu-Chi Yang The influences of selfregulated learning support and prior knowledge on improving learning performance.

Vishnumolakala, et,al (2017). Students' Attitudes, Self-Efficacy And Experiences In A Modified Process-Oriented Guided Inquiry Learning Undergraduate Chemistry Classroom,

Willis,J.2000. The Maturing of Contructivist Instruction Design: Some Basic Principilis that can Guide Practice. Educational Technology, 40(1).516.

Wetzels, S. A. J., Kester, L., \& Van Merriënboer, J. J. G. (2011). Adapting prior knowledge activation: Mobilisation, perspective taking, and learners' prior knowledge. Computers in Human Behavior, 27(1), 16-21. 
Wolters, Christopher. A., Pintrich, Paul. R., dan Karabenick, Stuart. A. 2003. Assessing Academic Self Regulated Learning. Conference on Indicator of Positive Development: Child Trends, National Institute of Health.

Zhu, Y.,Anu, W., Yates, G. 2016. University student's self control and self regulated learning in a blended course. Journal internet and highereducation, 30, 54-62. 